\title{
Wellen's syndrome or traumatic jaw pain?
}

\author{
Muhammad Hamza Saad Shaukat (1) , ${ }^{1,2}$ Muhammad Asim Shabbir, ${ }^{2}$ Hiren Patel (i) , \\ James Obrien ${ }^{4}$
}

${ }^{1}$ Aga Khan University, Karachi, Pakistan

${ }^{2}$ Internal Medicine, Albany Medical College, Albany, NY, USA

${ }^{3}$ Cardiology, Albany Medical College, Albany, NY, USA

${ }^{4}$ Capital Cardiology Associates, Albany, NY, USA

\section{Correspondence to}

Dr Muhammad Hamza Saad Shaukat;

hamzasaad1991@gmail.com

Accepted 25 September 2019

Check for updates

(c) BMJ Publishing Group Limited 2019. No commercial re-use. See rights and permissions. Published by BMJ.

To cite: Saad Shaukat MH, Shabbir MA, Patel $\mathrm{H}$, et al. BMJ Case Rep

2019;12:e232504.

doi:10.1136/bcr-2019-

232504

\section{DESCRIPTION}

A 51-year-old woman, active smoker, presented to the emergency department for left-sided non-radiating jaw pain over the last 1 day, associated with perioral paraesthesia. Three days prior, she was punched on the left side of her face by her domestic partner. Medical history included cocaine abuse (last used over a week ago) and non-adherence to medication for bipolar disorder. The patient denied nausea, vomiting, blurred vision, chest pain, dyspnoea, diaphoresis or loss of consciousness. On examination, she was fully oriented with an appropriate affect-there was mild tenderness, but no swelling or skin discoloration over the left jaw. Serum calcium was normal. CT scan revealed a non-displaced fracture of the left ramus. Urine drug screen was positive for cannabinoid and opiates. Although normotensive, bradycardia (40 beats per minute) prompted further evaluation with a 12-lead ECG (figure 1).

Wellen's syndrome is associated with critical stenosis of the proximal left anterior descending artery (LAD). ${ }^{1}$ It is characterised by an electrocardiographic pattern of biphasic or deeply inverted T-waves in leads V2-3 (may involve V1-6); ST segment deviation and $\mathrm{q}$-waves are not present. Cardiac biomarkers are normal or minimally elevated (serial troponin measurements were negative in this patient). ECG changes persist even when patients are asymptomatic. ${ }^{2}$

It was difficult to ascertain if the onset of jaw pain 2 days after the assault is musculoskeletal or

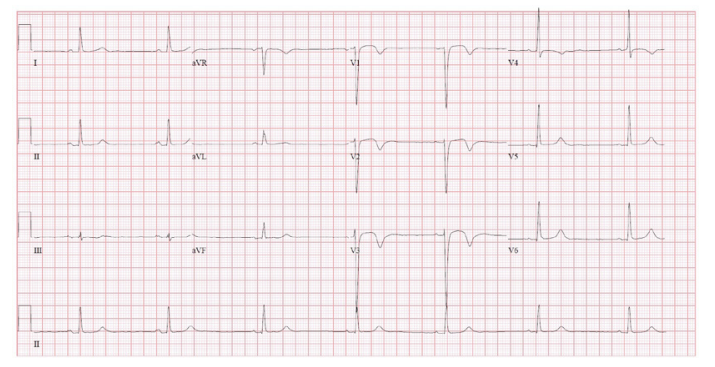

Figure 1 12-lead ECG showing biphasic T-waves in leads V1-3.

\section{Learning points}

- Identification of Wellen's syndrome on electrocardiography is potentially lifesaving because most patients have atypical presentation.

- Stress testing carries the risk of precipitating myocardial infarction.

cardiac. However, the electrocardiographic pattern warranted invasive coronary angiography which showed $40 \%$ proximal-mid LAD stenosis. Percutaneous coronary intervention was not performed (fractional flow reserve 0.88). Left main, right coronary and circumflex arteries did not appear diseased.

Secondary preventive therapy was initiated. Bradycardia resolved spontaneously. Followed closely outpatient, she remains at high risk for anterior myocardial infarction. Identification of Wellen's syndrome on electrocardiography is potentially lifesaving because most patients have atypical presentation. Stress testing carries the risk of precipitating myocardial infarction.

Contributors MHSS and MAS drafted the manuscript. HP and JO edited the submission.

Funding The authors have not declared a specific grant for this research from any funding agency in the public, commercial or not-for-profit sectors.

Competing interests None declared.

Patient consent for publication Obtained.

Provenance and peer review Not commissioned; externally peer reviewed.

\section{ORCID iDs}

Muhammad Hamza Saad Shaukat http://orcid.org/0000-00023740-7790

Hiren Patel http://orcid.org/0000-0002-1589-791X

\section{REFERENCES}

1 Rhinehardt J, Brady WJ, Perron AD, et al. Electrocardiographic manifestations of Wellens' syndrome. Am J Emerg Med 2002;20:638-43.

2 Schears MR, Sleigh BC, Ganti L. Wellen's syndrome: is one electrocardiogram good and plenty? Cureus 2019;11:e4394. 
Copyright 2019 BMJ Publishing Group. All rights reserved. For permission to reuse any of this content visit https://www.bmj.com/company/products-services/rights-and-licensing/permissions/

BMJ Case Report Fellows may re-use this article for personal use and teaching without any further permission.

Become a Fellow of BMJ Case Reports today and you can:

- Submit as many cases as you like

- Enjoy fast sympathetic peer review and rapid publication of accepted articles

Access all the published articles

Re-use any of the published material for personal use and teaching without further permission

Customer Service

If you have any further queries about your subscription, please contact our customer services team on +44 (0) 2071111105 or via email at support@bmj.com.

Visit casereports.bmj.com for more articles like this and to become a Fellow 